\title{
The DeVelopment OF CASE-BASED MOdule to IMPROVE STUdentS LEARNING OUTCOMES IN CITIZENSHIP EDUCATION
}

\author{
Sistriana $^{1)}$, Aunurrahman $^{2)}$, Andy Usman $^{3)}$ \\ ${ }^{1)}$ Universitas Tanjungpura, Pontianak, Indonesia \\ E-mail:shes3ane@gmail.com \\ ${ }^{2)}$ Universitas Tanjungpura, Pontianak, Indonesia \\ E-mail: aunuruntan@gmail.com \\ ${ }^{3)}$ Universitas Tanjungpura, Pontianak, Indonesia \\ E-mail: andyusman567@gmail.com
}

\begin{abstract}
This study aims to determine the development of case-based modules through a module-based design development case material on Diversity of Tribes, Religion, Race and Intergroup in the Frame of Bhinneka Tunggal Ika, and to see how the implementation and acquisition of learning using case-based modules with research subjects of class VIII students who have studied the material. The research method used in this study is a development research method by combining Borg \& Gall's development model with the Dick \& Carrey learning design model. Data obtained through interviews, observations and tests applied to the subject of the study. The flow of this research is carried out through three main stages, namely (1) Product development plan phase, which includes analysis of learning objectives, learning analysis, identification of student characteristics, formulating objectives and planning of learning media, (2) Stage of product development, which includes product development, developing test instruments, developing learning strategies, developing and selecting instructional materials, designing and developing evaluation drafts, revising learning packages, and (3) testing and revision stages, which include small group trials, initial product revisions, medium scale tests, revisions second test of result product, and large-scale trials. The results showed a high percentage of the feasibility of learning activities, namely $84.26 \%$ in teacher activities and $83.33 \%$ in student activities. Learning gain that can be achieved by using case-based modules is the activity of students in learning activities and an increase in the percentage of mastery learning in the pretest and posttest implementation, from $20 \%$ to $46.67 \%$. And viewed from the aspect of increasing understanding of the attitudes that must be had regarding the diversity of tribes, religions, races, and intergroup obtained through assessment instruments attitudes as a whole reached an average of 4, which means that some students consider each aspect important to ethnic diversity, religion, race, and intergroup.
\end{abstract}

Keywords: Case-Based Modules; Learning Outcome; Citizenship Education

\section{INTRODUCTION}

As is known, Citizenship Education is one of the subjects whose focus is orientation in general, directed to shape students to become individuals who have integrity towards the nation and state. In particular Citizenship Education is directed at forming students who are law-abiding, polite, and have manners according to the Indonesian nation's personality, namely the Pancasila.

According to the opinion of Malik Fajar in Zubaedi (2012: 277), "Civics become a vehicle to develop the abilities, character, and character of democratic and responsible citizens." Through Citizenship Education students are expected to know what is good and not good to do where this action is the application of the results of students' understanding of the material presented.

To achieve the goal above there are many things that must be prepared by the teacher. Among them are facilitating students with learning resources that are able to meet the learning needs of the students themselves. As explained in Majid (2009: 170), "learning resources are also interpreted as all places or the surrounding environment, objects and people who contain information can be used as a vehicle for students to carry out the process of changing behavior." 
One source of learning that is often used is textbooks. The textbook itself has a function as teaching material, where through this teaching material students can obtain information relating to the skills that must be obtained. As explained in Majid (2009: 173), "with teaching materials allows students to learn a competency or basic competency in a coherent and systematic manner so that accumulatively able to master the competence as a whole and integrated."

In another sense, through the use of textbooks students can increase their understanding of material. Through mastery of these competencies will have an impact on increasing learning gain. In order for the benefits of the book to be felt it is necessary to fulfill the provisions of a good textbook. Explained in Anshory (2013: 84), "a good book is a book written in a language that is good and easy to understand, presented interestingly equipped with pictures and information - information."

In South Jawai 1 State Junior High School, textbooks are also the main teaching material used in classroom learning activities. Textbooks are used intended to provide convenience to students in learning. In textbooks, solid and detailed descriptions are provided with the intention that students are able to absorb information so that they are able to understand each material concept according to the specified competencies. However, in reality, students still lack the students' ability to absorb this material. Even students tend to experience boredom which results in a decrease in learning gain. For example, from the cognitive aspects of the daily test scores of class VII students at South Jawai 1 State Junior High School on the material Diversity of Tribes, Religion, Race, and Intergroup in the Frame of Unity in Diversity as learning gains from cognitive aspects seemed low. Of the 3 races with 94 number 7 students, only $31.05 \%$ were able to achieve grades with complete criteria.

If it is associated with existing value data, this situation correlates with learning activities in the classroom through preliminary studies conducted by researchers. Through simple question and answer, information is obtained that students tend not to be interested in the density of the material presented in the textbook.

As is known, Citizenship Education subjects are actually included in social science groups where the material in them is a simple form of social phenomena that occur in everyday life, which is real and often occurs in the environment of the students themselves. So that to obtain meaningful learning outcomes children need to jump in direct contact with the community environment instead of memorizing text by text. In accordance with what was described by Rusman (2014) in Basit (2015: 2) that, "learning is more meaningful when schools are closer to the community environment functionally." This means that the school is always close to the community in the physical sense but in terms of its role. Furthermore, Rusman (2014) in Basit (2015: 2) explained that "teaching materials in schools always come into contact with life situations and problems that occur both within the family and the community environment."

Aside from being a subject related to social phenomena, Citizenship Education is also an essential subject that actually talks about personality formation. In accordance with Wardana's opinion (2013: 55) explained "Citizenship Education is Personality Education. So it is impossible to explain with a long description ". If it is still done with a complicated explanation, this will make students lose motivation in learning. Re-explained by Wardana (2013: 55), "students are less interested in PKn lessons, they consider Civics as memorization subjects, not paying attention to reasoning aspects so that student learning outcomes become low." From these reasons, it is necessary to find a way for students not to lose motivation in their learning activities.

Presenting cases is one way that can be used to be able to change student learning patterns from memorizing to understanding. By understanding, the affective side of students will be more honed which of course will also affect the other side, in this case, cognitive and affective. Through cases, students are not required to memorize the text, but understand every meaning of the phenomenon. And from this, meaningfulness in learning is obtained.

Based on the problems that have been described, the focus of this research is "Case-Based Module Development to Increase Learning Achievement of Diversity in Ethnic, Religious, Racial, and Intergroup Material in the Frame of Unity in Diversity in Class VII Citizenship Education Subjects.

\section{METHODOLOGY}

This type of research to be carried out is a type of development research, so the method used is also a method for development research. The cycle used to develop educational products starts with (1) Research and information gathering, (2) Planning, (3) Developing initial product forms, (4) Initial field tests, (5) Revision of main products, (6) Field tests main, (7) Revision of operational products, (8) Test of operational fields, (9) Revision of final products, (10) Dissemination and implementation.

The cycle is combined with Dick and Carey's Learning Design Model which consists of ten learning design steps as mentioned in Personal (2010: 99), namely, (1) identification of learning objectives, (2) instructional analysis, (3) analysis of student characteristics in learning context, (4) formulating specific learning objectives, (5) developing assessment instruments, (6) developing learning strategies, (7) developing and selecting teaching materials, (8) designing and developing formative evaluations, (9) revising programs learning, (10) designing and developing summative evaluation.

Qualitative data analysis was carried out to find out the results of validation conducted by experts by testing the quality of case-based modules that have been designed. The qualitative analysis in this study consisted of media expert validation, material expert validation, and validation of learning design experts. The validation results of both modules and research instruments will be rated with validity categories such as very valid, valid, invalid, and invalid. These categories are then interpreted in criteria for the range 
of numbers obtained from the scoring of questionnaire data collection results. Quantitative data analysis techniques are used by researchers to analyze the results of expert test validation regarding case-based modules. In this case, the product test is in the form of case-based modules compiled by researchers as teaching materials in learning activities. This product test aims to see the effectiveness of product use.

In order for the effectiveness of the product to be tested, it is necessary to give pre-test and posttest treatment. Where the pretest by looking at learning gain without using a casebased and posttest module with learning gain after using a case-based module. The results of this analysis are called pretest and posttest one group design.

\section{RESULTS AND DISCUSSION}

\section{A. Results}

\section{Design of Case-Based Module Development}

The design used in developing this case-based module is the collaboration model development of Borg \& Gall with the learning design model Dick \& Carrey. In the previous presentation, the design of the development began with planning the development of a case-based module that began with identifying learning objectives in order to find the form of student learning difficulties.

The learning objectives used to refer to the syllabus used by the education unit, namely the syllabus of secondsemester junior high school Civics Education subjects. As stated in Pribadi (2010: 101), "the formulation of learning objectives can be developed from the syllabus used."

The next step in the design of case-based module development is to conduct learning analysis by determining the number of abilities students must possess. This is done with the aim that every desired achievement must have its own target. Determination of competencies achieved is also formulated in accordance with the competencies listed in the syllabus of class VII Secondary Citizenship Education subjects.

After conducting an analysis of learning, the next step is to identify the characteristics of students related to students' ability to understand the material Diversity of tribes, religions, races, and groups. Pribadi (2010: 102) mentions, "analysis of student characteristics include the actual abilities students have in learning." The actual abilities of these students can be seen from the results of the daily tests performed.

The percentage of completeness shows low results in the assessment of knowledge. Only 6 out of 32 students were able to achieve 75 completeness scores. Meaning the percentage of completeness that was able to be achieved was at $18.75 \%$. In addition, from the initial (pre-research) subject teachers stated that students have low motivation in learning, the ability to understand long description texts, and lack of skills in expressing their attitudes towards other people's opinions or issues that develop in their environment.

The next step is to determine specific objectives related to the specific abilities students must possess after learning the material of ethnic, religious, racial, and intergroup diversity with certain indicators, such as being able to write or write, able to group, apply and so on. The formulation of this learning objective is also a reference in formulating tests that are used to measure the increase in skills acquired by students after using the case-based module used.

The next step is to determine the media tailored to the facilities owned. According to Sanjaya's opinion (2011: 145) that, "learning activities oriented to student activities are influenced by the availability and use of the media." Therefore the media that is utilized is media that can be operated with the facilities that the school has. The forms of media that can be used include audiovisual media and visual media that are displayed using a projector.

The next stage is the development of a case-based module that begins with product development. In the case-based module preparation, the first thing to do is to collect material from several kinds of literature such as the mandatory student handbook, teacher books, and some other supporting literature. The preparation of this module also pays attention to the material sequences that are adjusted to the competency sequence listed in the curriculum (according to the learning syllabus).

The next step is the development of assessment instruments in the form of test questions (pretest \& posttest) that are used to measure the level of knowledge competency before and after the use of case-based module products in learning. Questions are made according to indicators that have been prepared beforehand in the form of a multiple choice of 20 questions.

In addition, the assessment instrument is also in the form of assessing the attitudes stated in the Likert scale. The attitude skills in question are the skills of the spiritual attitude and social attitudes of the students. Item statements are prepared based on indicators that have been determined according to competency attitudes that must be achieved after the learning activity ends. Attitude assessment instruments are made consisting of grids and items of attitude statements totaling 12 statements expressed with the attitude that is Very Important, Important, Neutral, Not Important, and Very Not Important.

The next step in developing a case-based module is to develop learning strategies. In the module enter activities examine cases in groups and presentations, to train students in diverse groups, train students to learn to interact with group friends, enable students to practice courage in expressing their opinions, respond to other people's opinions, and no less important to train students to respect the opinions of others as a form of tolerance between fellow students. Besides learning strategies with group work also aims to build active learning activities, as explained in Silberman (2014: 47) that, "group work is an important part of forming active learning activities."

After all the initial product development series (casebased modules) were completed, the next activity was to compile a draft evaluation in the form of a validated instrument to assess the feasibility of using a case-based module. After this assessment instrument is prepared a case- 
based module through the stages of validation involving two material experts, one learning design expert, and two media experts.

Evaluation of product validation results on material aspects with an overall value of the overall aspects of 3.95 (consisting of 5 aspects with 11 items of questions). Assessment of product validation results on aspects of learning design with an average value of all aspects of 3.63 (consisting of 8 aspects with 12 items of questions).

Evaluation of product validation results on media aspects with an average value of all aspects of 4.12 (consisting of 5 aspects with 12 items of questions). The averages of the validation from the material experts, learning design experts, and media experts are presented in Table I.

TABLE I

AVERAGE RESUltS OF MATERIAL EXPERT, LEARNING DESIGN EXPERT, AND MEDIA EXPERT VALIDATION

\begin{tabular}{clcc}
\hline No & \multicolumn{1}{c}{$\begin{array}{c}\text { Validation } \\
\text { Aspects }\end{array}$} & $\begin{array}{c}\text { Aspects } \\
\text { Average }\end{array}$ & Criteria \\
\hline 1 & Material Expert & 3,95 & Valid \\
2 & Learning Design & 3,63 & Valid \\
& Expert & & Very Valid \\
\hline
\end{tabular}

The criteria for this validation refer to the validation criteria according to Khabibah 2006 in Maslikhah and Kusrini (2014: 9), stating that, "the predicate value is very valid $4 \leq$ RModule $\leq 5$, Valid $3 \leq$ RModule $<4$, Valid $2 \leq$ RModul $<3$, and Invalid $1 \leq$ RModul $<2$ ".

The next step is to carry out trials on the subject of the research, namely VIIC class students of South Jawai 1 State Junior High School, which is started by small group trials (one - one) involving 3 students randomly selected with activities in the form of individual learning activities and fill out student response questionnaires to find out student opinions and case-based module improvement suggestions used in learning activities. From the assessments and suggestions given, the researcher revised the case-based module and continued the medium group trial.

Group trials are being conducted with the trial subjects 6 students randomly selected. In this medium group trial the activities carried out were the same as small group trials. It's just that in this medium group trial a trial of learning scenarios will also be conducted which will be applied to large-scale trials (field). Assessment of student responses and suggestions was also collected in this second trial. The researcher made the final revision based on the suggestion of the medium group trial test subjects. Revisions were also made to improve the learning scenario that will be carried out in the trial of large groups.

After a series of trials and revisions in the small and group groups are being completed, the researchers conducted a trial on a wider group of trials on all research subjects, namely students of class VII C with a total of 30 people. Where in this trial a revised learning scenario was applied after the second trial. In this large group trial, a series of activities were also carried out measuring the initial knowledge possessed by students through the posttest, pretest, and assessment of student responses to this case-based module.

TABLE II

CASE-BASEd Module PhySiCAL SAMPLES

Cover of Case-Based Content
Modules
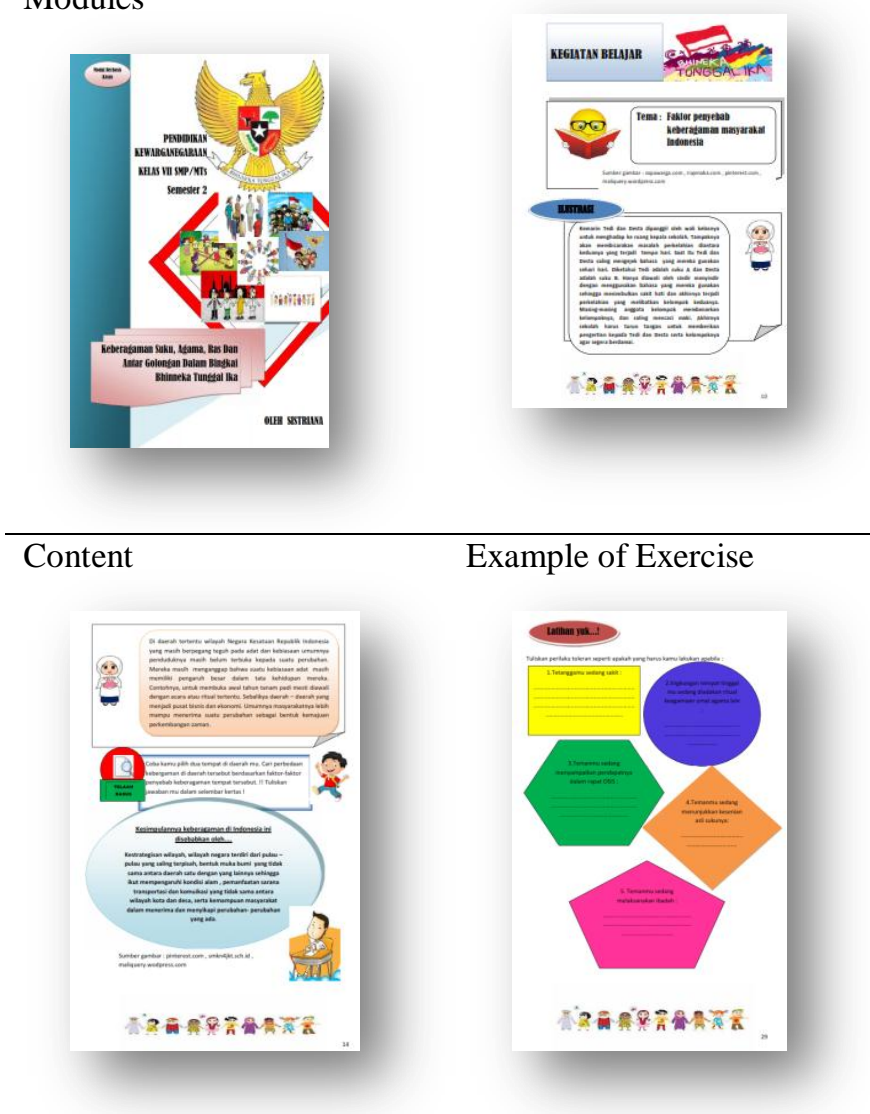

Example of Exercise

Implementation of Learning Using Case-Based Modules

Learning activities using this case-based module are monitored by observers to assess what learning activities look like. This activity is recorded in the observation sheet of learning activities according to aspects of observation. This aspect of observation consists of observing the activities of the teacher (introduction, core activities, and concluding) and observing the activities of the students (introduction, core activities, and concluding). This observation was conducted to see whether the aspects of the observation process of the learning process were carried out or not.

The teacher activities that are prioritized in this observation activity are teacher activities which can facilitate students to do more in their learning activities. This means that teacher activities are directed to activities that can make students actively involved in learning activities so that they can realize effective learning. This involvement can give students the opportunity to understand the lessons so that student achievement can increase. This is in accordance with what Khodijah (2014: 182) states, "effective learning provides opportunities for students to more easily understand 
lessons that can ultimately improve students' own learning achievement."

Viewed from the results of observations of the activities carried out by the teacher in the learning process, the percentage of implementation of the observation items reached $84.26 \%$. This means that most of the observation items checked by the observer are "there" choices that can be interpreted that the observation items are carried out by the subject teacher during the learning activities. The remaining $15.74 \%$ is not carried out by the teacher concerned. The details of the implementation of teacher activities observed $83.33 \%$ of the preliminary activity items were carried out, $94.44 \%$ of the core activities were carried out, and $75 \%$ of the closing activities were carried out.

Furthermore, when viewed from the activities carried out by students who were the items of observation in the classroom observations the activity was $83.33 \%$. This means that most of the observation items checked by observers are "there" choices that can be interpreted that the observation items are carried out by students during learning activities. This can be interpreted that students are active in the learning process that takes place. As explained in Bistari (2017: 35) that, "the learning process does not take place if it is not accompanied by the activity of students in it." From the results of the observation, only $16.67 \%$ of the rest was not carried out by the students observed. The details of the implementation of student activities observed $83.33 \%$ of the preliminary activity items were carried out, $100 \%$ of the core activity items were carried out, and $66.67 \%$ of the closing activities were carried out.

In the implementation of case-based learning, students are able to activate themselves in the learning process. This can be seen from their courage to ask good questions related to teaching materials in the form of case-based modules that they received. Not only that they seem more courageous to try to express opinions, or even respond to other people's opinions. So that it can be interpreted that the motivation for learning is quite visible. The existence of motivation is very important to create conditions for learning activities, in accordance with what was stated in Bistari (2017: 36-37) that, "motivation becomes one of the psychological conditions that affect student learning activities."

\section{Obtaining Learning by Using a Case-Based Module}

The purpose of using case-based modules is basically to provide convenience for students in learning material. The ease of learning has implications for the final results of a learning process. As explained in Bistari (2017: 90), "the end of the learning process is the acquisition of a student learning outcome. Which is the result of the interaction between learning and teaching? " This learning acquisition is in the form of the end result of learning activities carried out by students both cognitively and effective.

The learning gain that shows the usefulness of this casebased module can be seen from the increase in the posttest value of the pretest. This means that there is an increase in absorption of the material being studied. As explained in Faturrohman and Sutikno (2010: 113), "one of the characteristics of learning success is shown by the absorption of teaching materials to achieve high achievement both individually and in groups."

From the results of the pretest implementation, the average score of 30 students was 54, and the average posttest score was 73.83 . If seen from the difference in the average number, it can be concluded that the value of students tends to increase after using case-based modules. Likewise, when student learning is seen from the percentage of completeness achieved, the average percentage of posttest completeness assessment is $46.67 \%$ with the average incompleteness reaching $53.33 \%$, where previously the pretest implementation average percentage completeness obtained is $20 \%$ with an average of $80 \%$ incompleteness. This means that the percentage of completeness has increased by $26.67 \%$. With this, it means that the use of case-based modules is considered sufficient to contribute to the increase in student learning even though some students have not been able to obtain grades according to minimum completeness, namely at number 75 .

This is also evidenced by the t-test which is conducted to determine the significant use of case-based module products, with a calculated $t$ value of 7.58. This value is greater than the value of $t$ table which is equal to 1.699 with a level of confidence $(\alpha)$ of 0.05 so that the value of t count $>$ from the value of $\mathrm{t}$ table. Thus it can be concluded that the use of case-based modules is quite significant in increasing the cognitive value of students in learning material Diversity of tribes, religions, races, and intergroup in a single frame of Bhinneka Tunggal Ika.

In more detail, learning acquisition can be seen through the ongoing learning process. In this learning process requires direct student activity. This activity is characterized by the involvement of students, according to what is mentioned in Karwati and Priansa (2014: 195), "student learning activeness is characterized by the direct involvement of students in learning activities." For example, students have the courage to ask questions related to the contents of a case-based module. This shows students have an interest in using the case-based module.

Then through the strategies applied in case-based module design can improve students' ability to interact with teachers, and more importantly, interact with fellow students. Students seem to have more courage to express their findings during learning activities. Students also have the courage to respond as a form of expressing their opinions on the issues discussed.

Besides that, the attitude aspect is also the focus of the assessment in this study. Attitude assessment is expressed in the form of scale. One of the types of affective domain assessments includes a number of things including recognition of judgments and attitudes towards something. As explained in Karwati and Priansa (2014: 202), "the assessment and determination of attitudes include several things such as acceptance of values, respecting, acknowledging, and determining attitudes." Assessment of affective aspects in this study is based on what students respond to items of attitude statement. Is considered very 
important, important, quite important, not important, and very not important. The aspects assessed in the attitude assessment consisted of 4 aspects with 12 statements.

Through this attitude assessment, it is known that the average total number of these aspects reaches 4.29. In the first aspect, which is to accept diversity as the gift of God Almighty, it is obtained an average of 4.47. The second aspect, which is to accept diversity, ethnicity, religion, race, and between groups, is obtained by an average value of 4.27 . The third aspect, which is manifesting in personal tolerance towards ethnicity, religion, race, and between groups, is obtained by an average value of 4.12 whereas the last aspect is that it is important to understand the diversity of ethnicity, religion, race and intergroup 4.32. Overall, the average score can reach 4 , so it can be concluded that most students understand and know the important meaning in addressing the diversity of tribes, religions, races, and intergroups.

\section{CONCLUSIONS}

Based on the results of the research that has been carried out, the following conclusions can be drawn:

1. Case-based module development plan through three main stages, namely stages: (1) product development plan; (2) initial product development; and (3) trials and revisions.

2. The implementation of learning used case-based modules through teacher activities and student activities. In the teacher's activity the percentage of the implementation of preliminary activities reached $83.33 \%$, core activities $94.44 \%$, and closing activities $75.00 \%$. In student activities, the percentage of implementation of preliminary activities reached $83.33 \%$, core activities reached $100 \%$, and closing activities $66.67 \%$.

3. Obtaining learning by using case-based modules can be seen from:

a. The existence of student activeness in learning activities that can be seen from observation activities and learning activities journals.

b. There is an increase in achievement of completeness criteria. The percentage at pretest is only $20 \%$ of students can achieve complete grades and at posttest can be increased to $46.67 \%$. At the pretest implementation the average score is 54 , and after the posttest, the average value can be increased to 73.83 .

c. Overall the average score is able to reach 4 , so it can be concluded that most students consider each aspect as important as the diversity of tribes, religions, races, and groups.

\section{REFERENCES}

Basit, Abdul. (2015). Proses Pembelajaran PKn Dalam Meningkatkan Kreativitas Peserta Didik Melalui Pembelajaran Berbasisi Masalah di SMAN 3 Probolinggo. Pedagogy, 3(1). ISSN 2354 - 6948.

Bistari. (2017). Mewujudkan Penelitian Tindakan Kelas. Pontianak: PT. Ekadaya Multi Inovasi.
Borg \& Gall. (1983). Educational Research. An Introduction. London \& New York: Longman.

Fathurrahman, Pupuh \& Sutikno, Sobri. (2010). Strategi Belajar Mengajar Melalui Penanaman Konsep Umum \& Konsep Islam. Bandung: Refika Aditama.

Karwati, Euis \& Priansa, Juni Donni. (2014). Manajemen Kelas. Classroom Managemen. Guru Profesional yang Inspiratif, dan kreatif, Menyenangkan, dan Berprestasi. Bandung: Alfabeta.

Khodijah, Nyayu. (2014). Psikologi Pendidikan. Jakarta: PT. Raja Grafindo Persada.

Majid, Abdul. (2009). Perencanaan Pembelajaran: Mengembangkan Standar Kompetensi Guru. Bandung: PT. Remaja Rosda Karya.

Maslikhah, Ailul \& Kusrini. (2014). Penerapan Strategi React dengan Menggunakan Pendekataan Konstektual Pada Materi Teorema Pythagoras di SMP N 1 Wonoayu Kelas VIII-H, MATHEdunesa Jurnal Ilmiah Pendidikan Matematika, 3(2).

Pribadi, Benny A. (2010). Model Desain Sistem Pembelajaran. Langkah Penting Merancang Kegiatan Pembelajaran Yang Efektif dan Berkualitas. Jakarta: Dian Rakyat.

Rusman. (2014). Model-model Pembelajaran (Mengembangkan Profesionalisme Guru). Jakarta: Raja Grafindo Persada.

Sanjaya, A. (2011). Model-Model Pembelajaran. Jakarta: Bumi Aksara.

Silberman, L. Melvin. (2014). 101 Cara Belajar Siswa Aktif. Bandung: Nuansa Cendekia.

Wardana, Ludfi Arya. (2013). Studi Kasus Pendidikan Kewarganegaraan di Kelas IV SDN Pisang Candi II Kota Malang. Pedagogy, 1. ISSN 2354 - 6948.

Zubaedi. (2012). Desain Pendidikan Karakter: Konsepsi dan Aplikasinya dalam Lembaga Pendidikan. Jakarta: Prenada Media Group. 